\title{
Kelekatan Antara Ibu dan Anak Usia Sekolah (Studi pada Ibu Sebagai Orang Tua Siswa Kelas 1 SDN Hanjuang Samijaya)
}

\author{
Meilanny Budiarti Santoso dan Megawati Batubara \\ meilannybudiarti13@gmail.com dan megawati.batubara@unpad.ac.id
}

\begin{abstract}
Mother possesses a central role in the process of educating children. Mother spends more time with children at home than in the school. Thus, the attachment between the child and the mother becomes a benchmark as having required the ability to perform interaction within constructed social relations of school-aged children. This study was conducted using an explorative study that focused on the 'eyecatching' of information and issues that obtained in the process of this study. Interview, observation and documentation techniques are applied. The results show that the attachment between mother and child is built on the basis of the various skills that must be owned by school-aged children. This also means the role and function of the mother in educating school-aged children, expecially teaching process, that is caring, willingness to share, respect, politeness and responsibility. Providing good role models is the best way to instill values in children, thus becoming the foundation for good attachment building between mother and child.
\end{abstract}

Keywords: attachment, mother, children, school-age children.

\section{Pendahuluan}

Seiring perjalanan usia seorang anak, semakin bertambahnya usia seorang anak, maka akan semakin kompleks perkembangan sosialnya, karena mereka semakin membutuhkan keberadaan orang lain. Hal ini tentunya sejalan dengan konsep dasar manusia sebagai makhluk sosial yang tidak akan mampu menjalani hidup seorang diri, sehingga manusia selalu membutuhkan orang lain untuk berinteraksi, karena interaksi sosial merupakan kebutuhan kodrati yang ada pada diri manusia.

Pertumbuhan dan perkembangan anak merupakan hasil interaksi antara faktor genetik, herediter, konstitusi dengan faktor lingkungan, baik lingkungan prenatal maupun lingkungan postnatal. Faktor lingkungan ini akan memberikan segala macam kebutuhan yang merupakan kebutuhan dasar yang diperlukan oleh anak untuk tumbuh kembangnya (Tanuwidjaya, 2002). Pada diri seorang anak, selain perkembangan fisik dan kognisinya, anak juga mengalami perkembangan aspek emosi dan sosialnya yang kemudian mengacu perkembangan konsep diri, kemandirian hidup, serta untuk penyesuaian diri (Depdiknas dalam Wibowo, 2007).

Proses tumbuh kembang seorang anak akan melalui berbagai macam tahapan pertumbuhan dan perkembangan dengan tugas perkembangan yang berbeda-beda pada setiap tahapannya. Keberhasilan pencapaian suatu tugas perkembangan pada satu tahapan perkembangan seorang anak akan membantu kelancaran pencapaian pada tahapan perkembangan berikutnya.

Secara umum, kesesuaian antara perkembangan anak dengan apa yang harus dicapainya dapat dilihat dari kematangan sosialnya (Wulandari, 2009). Dengan berbekal kematangan sosialnya, seorang anak akan lebih mudah untuk berorientasi dan bersosialisasi dengan dunia luar, yaitu dengan lingkungan masyarakatnya. Selain itu, kematangan sosial pun akan mempermudah anak untuk melakukan hubungan sosial secara mandiri, yaitu tidak menjadikan seorang anak berkembang menjadi individu yang bergantung pada lingkungan sosialnya. Kematangan sosial adalah hal yang berkaitan dengan kesiapan anak untuk terjun dalam kehidupan sosial dengan orang lain yang bisa 
diamati dalam bentuk keterampilan yang dikuasai dan dikembangkan, sehingga akan membantu kematangan sosialnya kelak (Doll dalam Habibi, 2006).

Ibu merupakan sekolah pertama bagi seorang anak, yaitu tempat anak-anaknya mendapatkan pendidikan untuk pertama kalinya dalam kehidupan mereka di dunia ini. Anak pun akan tumbuh dan berkembang dengan baik serta memiliki kepribadian yang matang apabila diasuh dan dibesarkan dalam lingkungan keluarga yang baik dalam menjalankan fungsinya. Dengan demikian, kehadiran orang tua (khususnya ibu) dalam perkembangan jiwa anak menjadi kunci utamanya. Bila anak kehilangan peran dan fungsi dari seorang ibu (karena ada juga keluarga yang terpaksa harus mengalihkan peran dan fungsi seorang ibu kepada orang lain yang dikarenakan oleh satu dan lain hal), maka anak akan kehilangan haknya untuk dibina, dibimbing dan diberi kasih sayang serta perhatian.

Keluarga, sekolah dan masyarakat sebagai faktor postnatal (faktor lingkungan yang mempengaruhi tumbuh kembang anak setelah lahir) merupakan pusat pendidikan bagi seorang anak, namun keluargalah yang memberikan pengaruh untuk pertama kali terhadap seorang anak. Keluarga merupakan pusat pendidikan yang paling berpengaruh terhadap perkembangan anak, karena dalam keluargalah ditanamkannya benih-benih pendidikan yang mengandung berbagai macam unsur untuk dapat melatih proses sosialisasi seorang anak. Artinya dalam proses pendidikan itulah dikembangkannya bagaimana anak dapat berprilaku sesuai dengan peran dan fungsinya di dalam kelompok saat berinteraksi sosial kelak.

Kelekatan (attachment) adalah ikatan kasih sayang dari seseorang terhadap pribadi lain yang khusus (Allish, 1998). Bowlby (dalam Shaffer, 2005) menyebutkan bahwa kelekatan merupakan ikatan emosional yang berlangsung secara timbal balik (reciprocal) antara anak dengan orang tuanya. Sementara Ainsworth (dalam Tomkinson \& Keasey, 1985) mengartikan kelekatan sebagai ikatan yang bersifat afeksional yang berkembang antara orang tua dan anak, terutama antara ibu dan anak.

Hubungan anak dengan orang tua merupakan sumber emosional dan kognitif bagi anak. Hubungan dengan orang tua atau pengasuh utamanya (dalam hal ini adalah antara anak dengan ibunya) menurut Bowlby (dalam Shaffer, 2005) akan membentuk suatu internal working model, yaitu representasi kognitif mengenai diri sendiri (diri anak), orang lain serta penerimaan lingkungan yang dibangun melalui interaksi yang terbentuk antara anak dengan ibunya.

Kelekatan anak dapat ditunjukkan pada satu individu atau lebih yang disebut figur lekat atau objek lekat. Anak dengan kelekatan aman (secure attachment) menggunakan orang tua sebagai dasar aman untuk mengeksplorasi dunia dan sebagai tempat aman untuk kembali mendapatkan dukungan emosional. Salah satu faktor yang mempengaruhi kulitas kelekatan anak menurut Shaffer (2005) adalah kulitas pengasuhan. Anak yang mendapatkan kelekatan (attachement) yang cukup, akan merasa aman (secure) dan lebih positif terhadap kelompoknya, menunjukkan interes yang lebih besar ketika mengajak bermain. Anak-anak ini juga lebih bersifat sosial tidak hanya dengan kelompoknya, tetapi juga dengan kelompok usia lain/intergenerasi (Matas dalam Hetherington \& Parke, 1999).

Secara kepribadian, anak yang mengalami kelekatan yang aman (secure attachment) akan lebih berkembang baik dalam hal-hal yang berpengaruh positif, seperti memiliki kemandirian, empati dan kemampuan-kemampuan dalam situasi sosial. Dengan demikian, hubungan kelekatan (attachment) ini merupakan dasar penting bagi tingkah laku selanjutnya (Matas, dalam Hetherington $\&$ Parke, 1999). Sebaliknya anak-anak yang kurang terpenuhi kebutuhan kelekatannya, baik yang ambivalen atau yang tidak aman, akan cenderung pasif, membutuhkan waktu yang lebih lama di 
dalam menyesuaikan diri dengan lingkungannya atau kelompoknya, dan kurang nyaman di dalam interaksi sosialnya (Matas, dalam Hetherington \& Parke, 1999).

Kemandirian merupakan kemampuan seseorang yang terbentuk dari pengalamanpengalaman yang ada melalui proses belajar untuk tidak bergantung pada orang lain, mempunyai rasa percaya diri, mampu mengambil keputusan dan bertanggungjawab atas segala sesuatu yang telah dilakukannya. Sebagai salah satu tugas perkembangan pada anak usia sekolah, bahkan pada anak usia dini, kemandirian perlu diperhatikan dan ditanamkan sejak dini. Di dalam pembentukan kemandirian pada diri anak bergantung pada beberapa faktor, salah satunya adalah kelekatan anak pada ibu.

Dalam penelitian ini, kelekatan antara ibu dengan anak, yaitu anak usia sekolah dasar tercermin dari beberapa proses yang dilakukan oleh ibu dalam mendidik anak untuk membangun kematangan diri anak. Proses tersebut ditunjukkan oleh perilaku anak (sebagai hasil dari proses pendidikan yang dilakukan oleh ibu) serta feedback yang diberikan oleh ibu terhadap perilaku yang ditunjukkan oleh anaknya tersebut.

\section{Metode}

Metode penelitian yang dilakukan dalam penelitian ini adalah sutdi eksploratif dengan pendekatan kualitatif yang akan menghasilkan data berupa penggambaran situasi, ucapan atau tulisan, perilaku dari orang-orang yang diamati serta menitikberatkan pada 'eye-catching' informasi dan persoalan yang diperoleh dalam perjalanan penelitian.

Proses pengumpulan data dilakukan dengan menggunakan teknik wawancara mendalam, observasi dan studi dokumentasi. Adapun instrument penggalian data yang digunakan dalam penelitian ini adalah pedoman wawancara, pedoman observasi dan kajian terhadap dokumendokumen yang terkait dengan isu dalam penelitian ini. Sejalan dengan hal tersebut, analisis data dilakukan melalui proses interative dan komparasi dari sejumlah informasi yang diperoleh dari hasil wawancara, pengamatan dan analisis dokumen.

\section{Hasil dan Pembahasan}

Aspek-aspek yang dikaji dalam penelitian ini mencakup proses pengajaran terkaitkepedulian, kesediaan untuk berbagi, mengajarkan untuk menghormati, mengajarkan sopan santun dan mengajarkan tanggungjawab. Berbagai aspek tersebut merupakan kecakapan yang akan membentuk anak dapat melakukan relasi sosial, tidak hanya dengan orang terdekatnya, yaitu ibu, melainkan juga dengan keluarga, teman-temannya dan juga dengan masyarakat di dalam lingkungan sosialnya, sehingga dapat mempererat kelekatan anak dengan ibunya dan juga dengan lingkungannya.

1) Kepedulian

Salah satu sikap anak untuk dapat menjalin relasi sosial dengan baik bersama teman-teman dan juga lingkungan sosialnya adalah dengan menunjukkan sikap kepedulian dari diri anak. Tentunya kepedulian anak tidak dapat terbentuk dengan sendirinya, melainkan harus melalui proses belajar. Terkait dengan cara ibu dalam mengajarkan kepedulian terhadap anaknya, dalam penelitian ini terdapat berbagai macam cara, yaitu dengan cara memberi contoh, mengajarkan kepedulian melalui tayangan televisi, mengajarkan kepedulian melalui keadaan sekitar yang dialaminya dan ada juga ibu yang tidak mengajarkan kepedulian kepada anaknya. 
Berdasarkan data lapangan, yang menarik adalah jumlah jawaban informan yang menyatakan memberi contoh kepedulian pada anak dan informan yang tidak mengajarkan kepedulian kepada anak, sama-sama menduduki jawaban mayoritas dan sama banyaknya. Tentunya data ini menarik untuk dikaji, karena berkaitan dengan keberadaan ibu dan fungsi yang diperankannya.

Apabila ibu sebagai faktor penentu yang akan memberikan 'warna' pada anaknya melalui proses didikan yang dilakukannya telah memutuskan untuk tidak mengajarkan kepedulian terhadap anaknya (sebagai salah satu kecakapan yang harus dimiliki oleh anak), maka hal ini dapat diartikan bahwa ibu tidak berfungsi dalam mengajarkan kepedulian, sehingga apabila tumbuh rasa kepedulian dalam diri anak di kemudian hari, hal ini tentunya karena pengaruh dari faktor eksternal (lingkungan) di mana anak tumbuh dan berkembang.

Dalam menjalankan fungsinya untuk mengajarkan kepedulian kepada anak, ibu memiliki berbagai macam cara yang dalam pelaksanaannya sering kali menggunakan kombinasi dari beberapa cara. Berbagai cara tersebut adalah sebagai berikut: berbagi mainan, peduli dengan sesama teman, berbagi makanan dengan teman, melihat pengemis, peka dengan orang lain, mengembalikan uang milik orang lain, melihat kondisi orang yang lebih susah, dan berbagi makanan dengan adik.

Tentunya dalam mengajarkan kepedulian kepada seorang anak, tidak dapat dilakukan secara instan, sehingga harus dilakukan berulang kali dalam setiap kesempatan yang ada dengan berbagai macam cara yang dapat dilakukan dan dipandang pas dengan berbagai situasi yang sedang dihadapi bersama antara ibu dengan anaknya tersebut. Dengan demikian, sangat dapat dipahami alasan ibu dalam mengajarkan kepedulian kepada anaknya, menggunakan berbagai kombinasi cara yang mungkin untuk dilakukan oleh ibu.

Seiring berjalannya waktu, ketika anak menjalin relasi sosial dengan teman dan lingkungan sosialnya, hasil pembelajaran yang diberikan oleh ibu kepada anaknya dapat dilihat hasilnya dalam sikap dan perilaku anak tersebut. Dalam penelitian ini, ditemukan telah terdapat berbagai macam bentuk kepedulian yang sudah tertanam pada diri anak, yaitu: berbagi mainan, memberi uang pada pengemis, berbagi makanan dan minuman, berbagi uang dan menanyakan kondisi orang lain. Tertanamnya berbagai macam bentuk kepedulian tersebut, faktanya berbeda-beda pada setiap anaknya, karena setiap anak tentunya memiliki pertimbangan dan pengalamannya masing-masing yang akan mendorongnya untuk memiliki rasa kepedulian.

2) Kesediaan untuk Berbagi

Kecakapan lainnya yang harus dimiliki oleh seorang anak agar dapat menjalin relasi sosial dengan baik adalah memiliki kesediaan untuk berbagi. Setiap anak, pada dasarnya dapat diajarkan dan dilatih untuk bisa berbagi atas apa yang dimilikinya. Berikut ini adalah barang-barang yang biasa digunakan oleh ibu dalam mengajarkan anak untuk berbagi, yaitu: makanan; uang dan makanan; uang; mainan dan makanan; makanan dan pakaian; mainan, makanan dan uang. Pemilihan barang yang dijadikan sebagai media untuk belajar berbagai tersebut disesuaikan dengan ketersediaan barang 
yang dimiliki dan sesuai dengan kemampuan dari masing-masing keluarga.

Dari berbagai macam jenis barang yang dijadikan sebagai media ibu dalam mengajarkan kecakapan untuk berbagai kepada anaknya tersebut, terdapat barangbarang tertentu yang sulit bagi anak untuk dapat membaginya dengan orang lain, baik itu dengan saudaranya, maupun dengan teman-temannya, yaitu terkait dengan barangbarang yang paling disukai dan disayangi oleh anak.

Proses belajar bagi seorang anak untuk bisa berbagi dapat dilakukan dengan berlatih bersama orang-orang terdekat dari diri anak. Berikut ini adalah pihak-pihak yang dijadikan oleh ibu sebagai media agar anak belajar untuk berbagi, yaitu dengan teman dan saudara, dengan saudaranya saja, berbagi pada saat ada musafir yang meminta-minta ke rumah dan belajar berbagi dengan semua orang.

Seperti halnya pada kecakapan sebelumnya (kepedulian), pada kecakapan kesediaan anak untuk berbagi pun, seorang ibu mengajarkannya dengan menggunakan kombinasi berbagai macam cara yang disesuaikan dengan situasi dan kondisi yang sedang dihadapi bersama antara ibu dengan anaknya. Namun demikian, ada pula ibu yang hanya mengajarkan berbagi pada anaknya dengan saudaranya saja. Hal ini dikarenakan sikap ibu yang protektif pada anaknya dan tidak membolehkan anak untuk bermain bersama temannya. Walaupun sikap ibu seperti itu, pada kenyataannya anak tersebut tetap memiliki kecakapan kesediaan untuk berbagi pada temannya, karena anak belajar dari keadaan di lingkungannya yaitu pada saat ada temannya di sekolah yang tidak memiliki pensil sedangkan dia memiliki beberapa pensil, anak tersebut pun kemudian mau memberikan pensilnya pada temannya tersebut. Hal ini menunjukkan bahwa, kecakapan kesediaan untuk berbagi pada diri anak pun dapat terbentuk karena adanya stimulus dari lingkungannya.

3) Kemampuan untuk Menghormati

Fungsi ibu dalam mendukung anak untuk dapat berinteraksi sosial dengan baik bersama teman dan lingkungan sosialnya, terutama dengan orang-orang yang lebih tua usianya dengan diri anak dan dengan orang lain yang sebelumnya belum dikenal oleh anak, maka kemampuan untuk dapat menghormati orang lain tersebut menjadi salah satu hal yang sangat penting untuk dimiliki oleh anak.

Dalam mengajarkan anak untuk dapat menghormati orang lain, seorang ibu melakukannya dengan berbagai macam cara, yaitu: mengajarkan menghormati orang yang lebih tua, mengajarkan meminta maaf dan berterima kasih; mengajarkan cara meminta izin dan memberi nasihat secara langsung.

Dalam mengajarkan kemampuan untuk menghormati orang lain, hal ini menjadi lebih efektif ketika langsung diberikan contoh oleh ibu melalui suri tauladan yang baik, sehingga anak akan lebih mudah untuk meniru sikap dan perilaku ibu ataupun orangorang terdekatnya dalam memberikan sikap hormat kepada orang lain.

4) Sopan Santun

Sopan santun adalah salah satu nilai penting yang harus dimiliki oleh seorang anak diantara berbagai macam nilai-nilai kebaikan lainnya dalam bersikap dan berperilaku terhadap orang lain. Untuk menjadi anak yang sopan dan santun, tentunya 
seorang anak harus diajarkan oleh orang tuanya, terutama oleh ibu sebagai sosok yang lebih lekat dan banyak waktu bersama anaknya.

Para informan memaparkan bahwa dalam mengajarkan sopan santun kepada anaknya, ibu melakukannya dengan berbagai macam cara, yaitu sebagai berikut: diberikan nasihat dengan memberikan contoh, berbicara dengan cara yang formal kepada yang lebih tua, dan tidak berkata kasar. Berbagai cara tersebut dilakukan dengan kombinasi diantara satu atau dua cara, yang disesuaikan dengan keadaan yang sedang dihadapi oleh anak dan ibu.

Terhadap hal yang menarik dalam hal kecakapan sopan santun pada diri anak, salah seorang ibu menyatakan bahwa ia tidak mengajarkan mengenai nilai-nilai sopan santun kepada anaknya. Namun, menariknya anak tersebut justru memiliki kemampuan untuk bersikap sopan santun terhadap teman-temannya dan juga dalam lingkungan sosialnya. Hal ini menunjukkan bahwa penanaman nilai-nilai lebih efektif dilakukan dengan memberikan suri tauladan secara langsung yang dilakukan oleh ibu ataupun oleh orang-orang terdekat dari anak, bila dibandingkan dengan cara mengajarinya dengan ucapan verbal maupun dengan pengajaran di sekolah secara formal.

5) Bertanggungjawab

Mendapatkan pendidikan termasuk salah satu hak yang harus diberikan oleh orang tua kepada anak-anaknya. Sekolah merupakan salah satu lembaga formal yang dapat memberikan pengajaran kepada siswa di bawah pengawasan guru. Agar anak mendapatkan pendidikan yang baik, maka salah satu tugas seorang ibu adalah memastikan kehadiran anak di sekolah. Kehadiran anak di sekolah juga merupakan tolak ukur bagi eksistensi diri ibu sendiri. Situasi yang terjadi dalam mengajarkan anak untuk dapat memenuhi kehadiran di sekolah adalah dengan cara ibu ikut mengantarkan anak ke sekolah dan ibu melakukan komunikasi dengan pihak sekolah ketika anak tidak bisa hadir ke sekolah.

Situasi di atas adalah bentuk pemenuhan dan pembelajaran dari nilai-nilai tanggungjawab, baik itu bagi diri ibu sebagai orang tua dengan menyekolahkan anaknya dan memastikan anaknya untuk memenuhi kehadirannya di sekolah, begitu pun dengan penanaman nilai-nilai tanggungjawab bagi diri anak dengan memenuhi kehadirannya di sekolah dan mengerjakan berbagai macam kewajibannya sebagai siswa di sekolahnya.

Mengerjakan pekerjaan rumah (PR) merupakan salah satu stimulus bagi anak untuk belajar bertanggungjawab dalam menjalankan kewajibannya sebagai seorang siswa. Mengerjakan PR bagi anak pun menjadi media untuk belajar membagi waktu, karena anak akan belajar untuk membagi waktu antara waktu untuk bermain dan waktu untuk belajar. Dalam penelitian ini, ditemukan lima ragam sikap anak dalam mengerjakan PR, yaitu: (1) anak langsung mengerjakan PR; (2) anak harus diingatkan dahulu; (3) anak sulit untuk mengerjakan PR dan harus dibimbing; (4) anak harus diingatkan tetapi masih sulit untuk mengerjakan PR, dan (5) anak malas mengerjakan PR dan berkata tidak ada PR.

Dari berbagai macam sikap anak dalam mengerjakan PR tersebut, sikap dominan yang ditunjukkan oleh anak-anak dalam penelitian ini adalah bahwa anak langsung 
mengerjakan PR dan anak harus diingatkan dahulu untuk mengerjakan PR. Hal ini menunjukkan bahwa anak-anak telah memiliki rasa tanggungjawab dalam mengerjakan kewajibannya mengerjakan PR dan sudah dapat membagi waktu, walaupun masih harus diingatkan terlebih dahulu oleh ibunya.

Dalam penelitian ini, hal menarik lainnya adalah terkait dengan sikap ibu saat menerima penolakan dari anaknya pada saat disuruh untuk mengerjakan PR. Berikut ini terdapat empat ragam sikap ibu ketika mendapatkan penolakan dari anaknya untuk mengerjakan PR, yaitu: (1) menasihati dan mendampingi anak untuk belajar; (2) anak belum pernah menolak mengerjakan PR; (3) tidak memaksa anak mengerjakan PR, dan (4) memarahi anak.

Dari keempat sikap ibu tersebut, sikap yang paling banyak diambil oleh para ibu ketika anaknya menolak untuk mengerjakan PR adalah menasihati dan mendampingi anak belajar (mengerjakan PR). Pemilihan sikap ini tentunya sangat dipengaruhi oleh faktor internal dalam diri ibu sendiri. Yaitu berupa kapasitas ibu untuk dapat mengendalikan emosi dan mengatur kehendak pribadinya (baik itu untuk alasan kebaikan saat ini ataupun untuk masa depan sang anak), sehingga ibu dapat dengan tenang dan jernih pikirannya untuk dapat menghadapi penolakan dari anaknya dengan cara terbaiknya, sehingga tidak menimbulkan permasalahan baru baik itu bagi diri ibu sendiri karena amarahnya, terlebih bagi anaknya karena terkena marah dari sang ibu.

Kelima aspek tersebut di atas, merupakan nilai-nilai dasar sebagai kecakapan yang harus dimiliki oleh seorang anak dalam menjalani relasi sosial dengan lingkungannya. Apabila anak dan ibu dapat menjalani semua proses saling belajar tersebut dengan sikap dan cara terbaiknya masing-masing, maka hal ini akan berbuah pada kelekatan antara ibu dengan anak (usia sekolah) yang terwujud dalam bentuk kemandirian dan keterampilan sosial pada diri anak yang baik, sebagai bekal anak usia sekolah dalam berinteraksi dan berelasi dengan lingkungan sosialnya.

\section{Kesimpulan}

Kelekatan antara ibu dengan anak (usia sekolah) tidak dapat dibangun hanya oleh salah satu pihak saja, melainkan harus saling bekerja sama diantara keduanya sebagai suatu tim yang akan saling mensukseskan dalam menjalankan fungsi dan perannya masing-masing, baik itu untuk diri mereka sendiri maupun fungsi dan peran mereka terhadap lingkungan sosialnya masing-masing, sehingga antara anak dan ibu, harus saling bekerja sama dalam membangun kelekatan diantara keduanya.

Ibu sebagai pembimbing dan pendidik bagi anaknya memiliki peran sentral bagi anaknya, bukan hanya untuk menjalankan fungsinya sebagai ibu, melainkan juga untuk memberikan suri tauladan bagi anaknya agar setiap nilai-nilai yang akan diajarkan pada anaknya dapat diserap dan dicontoh oleh anaknya dalam menjalani kehidupannya. 


\section{Bibliografi}

Doll E, 1965, Vineland Social Maturity Scale Condensed Manual Of Directions, Minnesota, American Guidance Service.

Habibi, M. 2006. Bimbingan Bagi Orang Tua Dalam Penerapan Pola Asuh Untuk Meningkatkan Kematangan Sosial Anak. Skripsi (tidak diterbitkan). Bandung: Universitas Pendidikan Indonesia.

Hetherington, E.M \& Parke, R.D. (1999). Child Psychology (5th edition). USA: McGraw-Hill Collage.

Puryanti, Imul. 2013. Hubungan Kelekatan Anak Pada Ibu Dengan Kemandirian Di Sekolah. Universitas Negeri Semarang.

Shaffer, David R. 2005. Social and Personality Development. USA: Thomson.

Tanuwijaya S. 2002. Konsep Umum Tumbuh dan Kembang. Dalam: Nahendra (penyunting) Tumbuh Kembang Anak dan Remaja. Edisi Pertama. Sagung Seto: Jakarta.

Tomlinson, Carol dan Keasey. 1985. Child Development. Homewood, Illinois: The Dorsey Press. Wibowo, 2007. Manajemen Kinerja, Edisi Kedua, PT. Raja Grafindo Persada, Jakarta. Wulandari, Diah, dkk. (2009). Asuhan Kebidanan Nifas, Jakarta: Buku Kesehatan. 